\title{
Comment on "Ultrahigh temperature granulites and magnesian charnockites: Evidence for the Neoarchean accretion along the northern margin of the Kaapvaal craton" by Rajesh et al.
}

\author{
O. Laurent ${ }^{\mathrm{a}, *}$, G. Nicoli ${ }^{\mathrm{b}, \mathrm{c}}$, A. Zeh ${ }^{\mathrm{a}}$, G. Stevens ${ }^{\mathrm{b}}$, J.-F. Moyen ${ }^{\mathrm{c}}$, A. Vezinet ${ }^{\mathrm{c}, \mathrm{b}}$ \\ a Institut für Geowissenschaften, Facheinheit Mineralogie, Johann Wolfgang Goethe Universität, Altenhöferallee 1, D-60438 Frankfurt am Main, Germany \\ ${ }^{\mathrm{b}}$ Centre for Crustal Petrology, Department of Earth Sciences, Stellenbosch University, Private Bag X1, Matieland 7602, South Africa \\ ' UMR 6524-CNRS-IRD, Université Jean-Monnet, 23 rue du Dr. Michelon, 42023 Saint-Étienne, France
}

\section{A R T I C L E I N F O}

Article history:

Received 15 May 2014

Accepted 14 July 2014

Available online 25 July 2014

\section{Introduction}

Over the years, the Southern Marginal Zone (SMZ) of the Limpopo mobile belt has been intensively studied, as it potentially results from one of the oldest continent-continent collision on Earth. Indeed, the general consensus about the evolution of this terrane is that it underwent a single tectono-metamorphic event at $\sim 2.7 \mathrm{Ga}$, ascribed to collision between the Kaapvaal and Zimbabwe Cratons (Barton et al., 2006; Eglington and Armstrong, 2004; Kröner et al., 2000; Kreissig et al., 2001; Roering et al., 1992; Rigby et al., 2008; Stevens and van Reenen, 1992a,b; Zeh et al., 2009). The study of the Limpopo belt, and in particular the SMZ, is therefore of primary interest to unravel the tectonic regimes that prevailed back in the late-Archean and their evolution throughout Earth history.

In a recent contribution, Rajesh et al. (2014) proposed a new "out-of-the-box" interpretation of the geological record in the SMZ, which would represent a micro-continent accreted to the northern margin of the Kaapvaal Craton during the Neoarchean at $2.72 \mathrm{Ga}$. The key element on which this interpretation is based is the spatial and temporal association of ultra-high temperature (UHT) granulites and magnesian charnockites, which would be a criterion to identify subduction and collision settings in Precambrian terranes. To demonstrate the occurrence of both rock types in the SMZ, Rajesh et al. (2014) provide (1) new zircon U-Pb ages of $2.72 \mathrm{Ga}$, obtained from metamorphic zircon overgrowths in proposed UHT metamorphic rocks, and (2) a new interpretation of major-element data from the spatially associated Matok pluton,

\footnotetext{
* Corresponding author. Tel.: +4969798 40133.

E-mail addresses: laurent@em.uni-frankfurt.de,oscarlaurent86@gmail.com (O. Laurent).
}

originally produced by Bohlender (1992), to reflect a magmatic arc setting at the time of intrusion.

This new interpretation, however, is in conflict with previous models and other published data, which strongly support that (1) the SMZ underwent metamorphism at "normal" granulite facies temperatures of $850-875^{\circ} \mathrm{C}$, with the preservation of a substantial volume of peak metamorphic biotite in most rocks; (2) granitoids of the Matok pluton were not generated within an arc setting but rather during the post-collisional stage of the ca. 2.72 Ga orogeny, as testified by both their age $(\sim 2.68 \mathrm{Ga})$ and chemical compositions; (3) the SMZ represent reworked material of the adjacent and overthrusted Pieterburg Block, and thus cannot have been an isolated terrane prior to amalgamation with the Kaapvaal Craton.

\section{UHT metamorphism}

A detailed comment on the occurrence of UHT metamorphism proposed by Belyanin et al. (2012) and Rajesh et al. (2014) was provided by Nicoli et al. (2014); the reader is referred to this work for further details, only the key points being repeated here. The $P-T$ estimates suggested by Belyanin et al. (2012) and Rajesh et al. (2014) (i.e. $\sim 1000^{\circ} \mathrm{C}$ and $\sim 12 \mathrm{kbar}$ ) are inconsistent with both field observations and experimental studies. The detailed metamorphic analysis provided by Taylor et al. (2014) clearly demonstrates that the presence of peak metamorphic biotite in the Bandelierkop formation metapelites is inconsistent with peak metamorphic temperatures in excess of $900^{\circ} \mathrm{C}$. This is in agreement with earlier metamorphic studies (e.g. Stevens and van Reenen, 1992a,b), more recent conclusions from phase equilibrium modelling (Koizumi et al., 2014), as well as a very large body of experimental data on partial melting of biotite-bearing metasediments (e.g. Montel 
and Vielzeuf, 1997; Patiño Douce and Harris, 1998; Patiño Douce and Johnston, 1991; Pickering and Johnston, 1998; Stevens et al., 1997; Vielzeuf and Holloway, 1988) arguing for a temperature peak around fluid-absent biotite breakdown partial melting conditions, i.e. $820-870^{\circ} \mathrm{C}$.

In addition to these considerations about the peak temperature attained by the SMZ, it is important to note that Rajesh et al. (2014) provide no metamorphic analysis for the two dated samples (i.e. DR-19C and DR-20). Therefore, it is not clear whether the obtained metamorphic ages documented by Rajesh et al. (2014) actually reflect peak metamorphism, and if so, if the dated samples underwent the same $P-T$ conditions as the sample used for the metamorphic study (i.e. DR-19A).

\section{Geochemical signature of the Matok pluton}

\subsection{Terminology issues}

Rajesh et al. (2014) suggest that the $\sim 2.68 \mathrm{Ga}$ granitoids of the Matok pluton are "magnesian charnockites", a family of rocks supposedly formed in subduction settings (Frost and Frost, 2008; Rajesh, 2012), being compositionally similar to arc magmas. In this context, it must be noted that the "charnockite" appellation used by Rajesh et al. (2014) is incorrect, because it should (strictly speaking) only be used for orthopyroxene-bearing granites (Frost and Frost, 2008). However, the Matok pluton is a composite intrusion, made up of different magmatic rocks having a wide range of silica contents $\left(\mathrm{SiO}_{2}=55-70\right.$ wt.\%; Laurent et al., 2014 and Fig. 5f-g of Rajesh et al., 2014), i.e. not only granites. This misuse is confusing, as Bohlender et al. (1992) clearly demonstrated that there are at least two different generations of orthopyroxene-bearing rocks in the SMZ, namely (1) metamorphic charnockites (sensu stricto), in which orthopyroxene is the dominant mafic phase and formed at the expense of biotite, presumably during dehydration melting, for example in the Baviaanskloof TTG gneisses; and (2) a suite of so-called "charnockitic rocks" (jotunites, enderbites and charnoenderbites), restricted to the Matok pluton and igneous in origin. These latter contain orthopyroxene in places, but always much less than clinopyroxene, and both phases are completely absent in the more felsic rocks (Bohlender, 1992; Laurent et al., 2014; Rapopo,
2010). Therefore, it is likely that several, if not most, of the samples plotted by Rajesh et al. (2014) in their discrimination diagrams are not charnockites at all, and probably not even orthopyroxenebearing.

\subsection{Matok granitoids are not similar to arc magmas}

Apart from the terminology issue, the geochemical arguments used by Rajesh et al. (2014) to discriminate the geodynamic setting of the "Matok charnokites" are also problematic. Indeed, the interpretation of magmatic arc affinity solely relies on the use of a few major-element data. In fact, many previous studies clearly showed that "subduction signatures" are commonly equivocal, even when trace element systematics are considered (e.g. Bédard, 2006; Rollinson, 2009; Willbold et al., 2009). The "magnesian" signature used by Rajesh (2012) and Rajesh et al. (2014) as a smoking gun to reflect a subduction origin is therefore not unambiguous, and could also characterize magmas formed in very different geodynamic environments. To support the magmatic arc setting, Rajesh et al. (2014) argue that the "Matok charnockites" formed by dehydration melting of amphibolites, in a roughly similar process to that proposed for the formation of Archean TTGs (e.g. Moyen and Martin, 2012 and references therein). However, Archean TTGs, although mostly magnesian in character, can be generated in a wide range of geodynamic environments (Fig. 1), not necessarily requiring a convergent plate margin (Moyen, 2011; Moyen and Martin, 2012).

In addition, the magnesian signature of the Matok "charnockites" is not that obvious. It is clear in Fig. $5 \mathrm{f}$ of Rajesh et al. (2014) that their samples are richer in Fe than typical charnockites from the Northern Marginal Zone (NMZ), several of them straddling the boundary between magnesian and ferroan groups defined by Frost et al. (2001). Moreover, the diagram presented in Fig. 5h of Rajesh et al. (2014) also shows that the Matok granitoids follow a very distinctive trend with respect to the NMZ ones, characterized by lower $\mathrm{Al}_{2} \mathrm{O}_{3} / \mathrm{CaO}$ ratios. These two characteristics (high $\mathrm{Fe}$ and low $\mathrm{Al}$ contents) have been recently highlighted by Laurent et al. (2014), who conducted a detailed petrogenetic study of the Matok granitoids on the basis of major-, trace element and Sm-Nd isotope geochemistry as well as geochemical modelling. In contrast to the suggestion made by Rajesh et al.

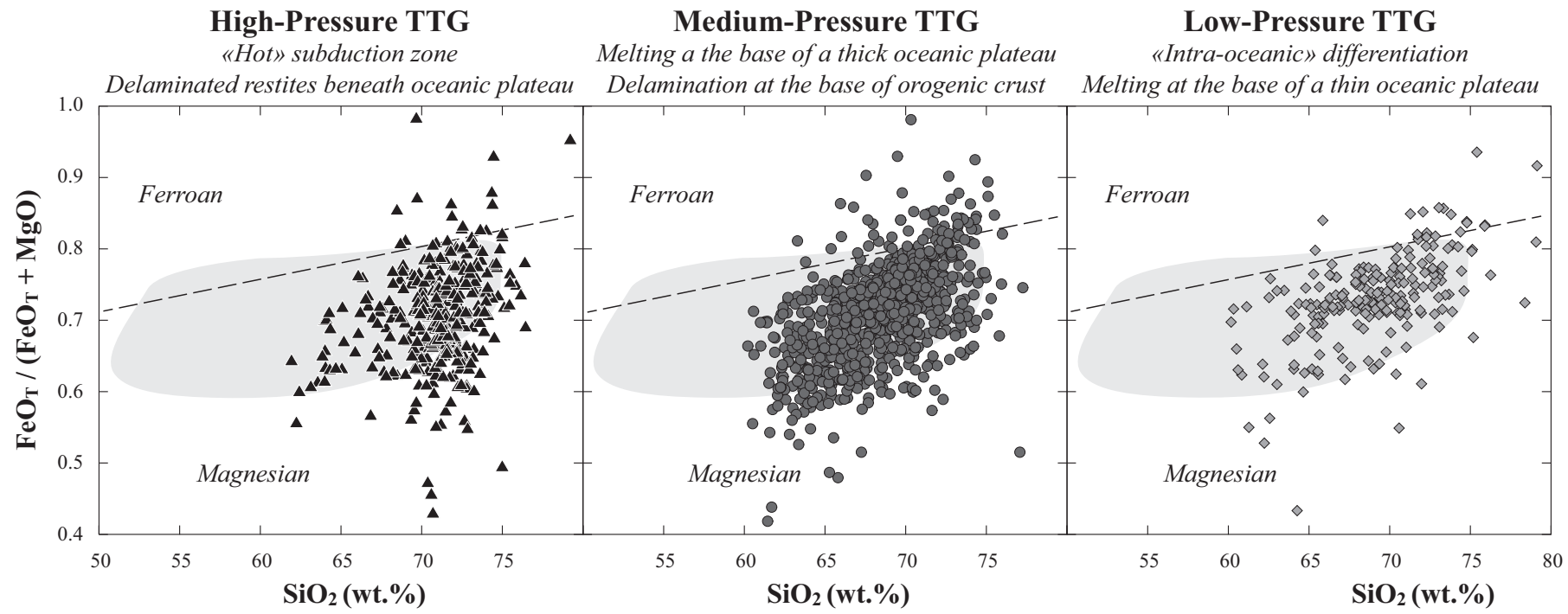

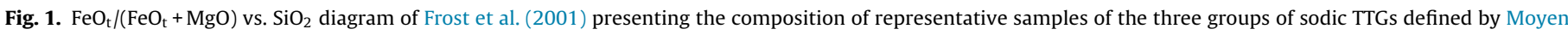

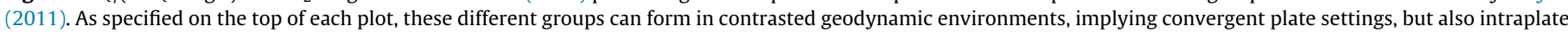

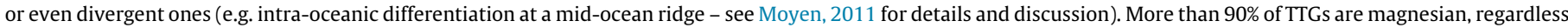

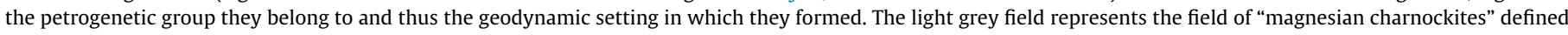
by Rajesh (2012). 


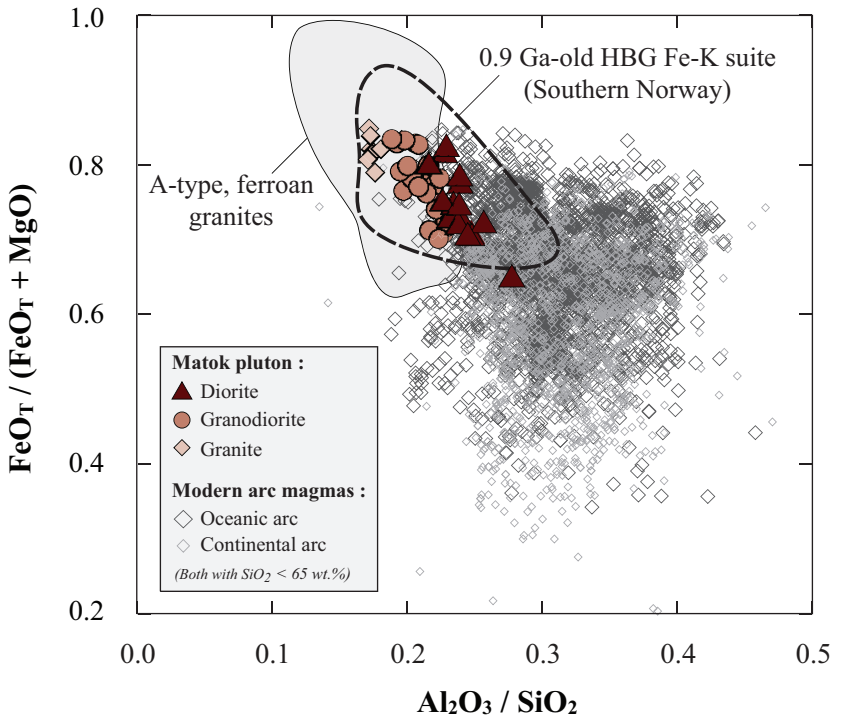

Fig. 2. $\mathrm{FeO}_{\mathrm{t}} /\left(\mathrm{FeO}_{\mathrm{t}}+\mathrm{MgO}\right)$ vs. $\mathrm{Al}_{2} \mathrm{O}_{3} / \mathrm{SiO}_{2}$ diagram where the whole-rock compositions of granitoids from the Matok pluton (data from Laurent et al., 2014) are reported, together with that of the Proterozoic "ferro-potassic" Hornblende-Biotite-Granitoid suite of southern Norway (data from Bogaerts et al., 2003 and Vander Auwera et al., 2007) as well as typical A-type, Fe-rich granites and modern subduction-related magmas from both continental and oceanic arcs ( $>5000$ samples from the GEOROC database). In average and at similar $\mathrm{SiO}_{2}$ contents ( $<65 \mathrm{wt} . \%$ ), rocks from the Matok pluton clearly show higher $\mathrm{FeO}_{\mathrm{t}} /\left(\mathrm{FeO}_{\mathrm{t}}+\mathrm{MgO}\right.$ ) and lower $\mathrm{Al}_{2} \mathrm{O}_{3} / \mathrm{SiO}_{2}$ than arc magmas.

(2014), Laurent et al. (2014) concluded that the Matok granitoids are akin to "ferro-potassic" suites, very common in Proterozoic terranes (e.g. Duchesne et al., 2010; Ferré et al., 1998; Peucat et al., 2005; Vander Auwera et al., 2011) and intermediate in composition between (1) Al-, Mg-rich sanukitoids and (2) Alpoor, Fe-rich anorthosite-mangerite-charnockite-granite (AMCG) suites. This intermediate composition is well illustrated in the $\mathrm{FeO}_{\mathrm{t}} /\left(\mathrm{FeO}_{\mathrm{t}}+\mathrm{MgO}\right)$ vs. $\mathrm{Al}_{2} \mathrm{O}_{3} / \mathrm{SiO}_{2}$ diagram of Fig. 2. This diagram also shows unequivocally that the Matok granitoids are globally more ferroan and less aluminous than modern, classical arc magmas from both oceanic and continental convergent margins (Fig. 2).

\section{Geodynamic model}

The geodynamic model proposed by Rajesh et al. (2014) is that the SMZ was a microcontinent, which was accreted to the northern margin of the Kaapvaal Craton by $\sim 2.72 \mathrm{Ga}$ at the latest, after a period of north-verging subduction. This interpretation, however, suffers two major problems:

(1) This model is in conflict with the fact that the Matok pluton (suggested to be subduction related) intruded at $\sim 2.68 \mathrm{Ga}$ (U-Pb age data of Barton et al., 1992; Laurent et al., 2013; Zeh et al., 2009), whereas terrane collision happened at 2.71-2.72 Ga, as indicated by U-Pb ages of metamorphic zircons obtained from granulite-facies rocks of the SMZ (Rajesh et al., 2014; Taylor et al., 2014). Furthermore, field observations and additional age data from the Hout River Shear Zone indicate that uplift and southward thrusting of the SMZ granulites over the Pietersburg block started prior to the intrusion of the Matok pluton, i.e. around 2.70 Ga (Kreissig et al., 2001; Laurent et al., 2013). In summary, the Matok pluton is clearly 10-30 Ma younger than the inferred age of collision, such that it cannot be related to subduction and rather represents a typical post-collisional intrusion as recently proposed by Laurent et al. (2014).
(2) Accretion of the SMZ as an individual microterrane to the northern edge of the Kaapvaal Craton is also at odds with previous studies based on Hf-Sr-Nd-Pb isotopes (e.g. Barton et al., 1992, 2006; Kreissig et al., 2000; Zeh and Gerdes, 2012; Zeh et al., 2009). These data unequivocally show that the SMZ and the adjacent rocks of the Pietersburg block actually belong to the same crustal domain. Specifically, the SMZ results from internal reworking of the Pietersburg block crust owing to continental collision at 2.72 Ga (Laurent et al., 2014; Zeh et al., 2009, 2013), with a northward-located terrane that could be represented by the Central Zone of the Limpopo belt. Internal reworking is for instance supported by $\mathrm{Pb}$ isotopic data indicating similarly low $\mu$-values $\left({ }^{238} \mathrm{U} /{ }^{204} \mathrm{~Pb}\right)$ of $\leq 10$ for all rocks of the Northern Kaapvaal Craton (including the SMZ), which are very different to the high- $\mu$ rocks exposed in the Central Zone of the Limpopo belt and the Zimbabwe Craton, both having values $\geq 11.5$ (Barton et al., 2006). Combined age and Hf isotope data also support that all granitoids of the northern Kaapvaal Craton, including the SMZ, formed by reworking of a single crustal component, which derived from a depleted mantle source between 3.3 and 3.0 Ga (e.g. Zeh and Gerdes, 2012; Zeh et al., 2009, 2013). Orthoand paragneisses from both the SMZ and the Pietersburg block also show undistinguishable $\mathrm{Nd}$ model ages (2.9-3.2 Ga), as well as similar major- and trace-element systematics (Kreissig et al., 2000). It is worthwhile noting, in addition, that detrital zircon grains in the metasedimentary samples investigated by Rajesh et al. (2014) yield ages of $\sim 3.40, \sim 3.33,3.00-2.95$ and $2.85-2.75 \mathrm{Ga}$. These ages actually correspond to the main magmatic episodes in the Pietersburg block (Laurent et al., 2013; Zeh et al., 2009). The youngest ages (2.85-2.75 Ga) are typical for granite emplacement (Turfloop batholith and associated intrusions; Henderson et al., 2000; Kröner et al., 2000; Laurent et al., 2013; Zeh et al., 2009), whereas all ages $\geq 2.95 \mathrm{Ga}$ are that of the Pietersburg TTGs (Kröner et al., 2000; Laurent et al., 2013; Zeh et al., 2009) and are also recorded by detrital zircons from low- to medium grade metasedimentary rocks of the Murchison and Pietersburg greenstone belts (Zeh and Gerdes, 2012; Zeh et al., 2013). All lines of evidence therefore support that rocks of the SMZ and the Pietersburg block belong to the same crustal domain, but underwent contrasted $P-T$ evolution during the $\sim 2.72$ Ga collision event.

\section{Conclusion}

The recent contribution by Rajesh et al. (2014) proposes a new geodynamic model for the evolution of the SMZ of the Limpopo belt and the Kaapvaal Craton in the Neoarchean, implying that both terranes were amalgamated at $\sim 2.72 \mathrm{Ga}$ as a result of northverging subduction and subsequent collision. The main supporting evidence for such a model is the spatial and temporal association of UHT granulites in one hand, and subduction-related magmatic rocks referred to as "magnesian charnockites" on the other hand. However, their arguments to support both (1) UHT metamorphic conditions in the SMZ; and (2) a subduction-related origin for the Matok granitoids are unreasonable and/or equivocal. Moreover, this new geodynamic model does not fit at all with the results of a great deal of previous studies in the area, and must therefore be regarded with some criticism.

Nevertheless, we believe that the data presented by Rajesh et al. (2014), especially their new U-Pb ages on detrital zircons from the SMZ, provide valuable information regarding (1) the timing of granulite-facies metamorphism and continental collision in this terrane; and (2) the provenance of the studied metasediments. These new data must be reconsidered in the scope of ongoing work 
about the evolution of the Pietersburg block and the SMZ during the Neoarchean.

\section{References}

Barton Jr., J.M., Doig, R., Smith, C.B., Bohlender, F., van Reenen, D.D., 1992. Isotopic and REE characteristics of the intrusive charnoenderbite and enderbite geographically associated with the Matok pluton, Limpopo belt, southern Africa. Precambrian Res. 55 (1-4), 451-467.

Barton Jr., J.M., Klemd, R., Zeh, A., 2006. The Limpopo belt: a result of Archean to Proterozoic, Turkic-type orogenesis? Geological Society of America Special Paper 405, 315-332.

Bédard, J.H., 2006. A catalytic delamination-driven model for coupled genesis of Archaean crust and sub-continental lithospheric mantle. Geochim. Cosmochim. Acta 70 (5), 1188-1214.

Belyanin, G.A., Rajesh, H.M., Sajeev, K., van Reenen, D.D., 2012. Ultrahightemperature metamorphism from an unusual corundum+orthopyroxene intergrowth bearing $\mathrm{Al}-\mathrm{Mg}$ granulite from the Southern Marginal Zone, Limpopo Complex, South Africa. Contrib. Mineral. Petrol. 164, 457-475.

Bogaerts, M., Scaillet, B., Liégeois, J.-P., Vander Auwera, J., 2003. Petrology and geochemistry of the Lyndgal granodiorite (Southern Norway) and the role of fractional crystallization in the genesis of Proterozoic ferro-potassic A-type granites. Precambrian Res. 124, 149-184.

Bohlender, F., 1992. Igneous and metamorphic charnockitic rocks associated with the Matok pluton and their significance in the Limpopo orogeny. Ph.D. thesis, Rand Afrikaans University, Johannesburg, South Africa.

Bohlender, F., Van Reenen, D.D., Barton Jr., J.M., 1992. Evidence for metamorphic and igneous charnockites in the Southern Marginal Zone of the Limpopo belt. Precambrian Res. 55 (1-4), 429-449.

Duchesne, J.C., Martin, H., Baginski, B., Wiszniewska, J., Vander Auwera, J., 2010. The origin of ferroan-potassic A-type granitoids: the case of the hornblende-biotite granite suite of the Mesoproterozoic Mazury complex, northeastern Poland. Can. Mineral. 48 (4), 947-968.

Eglington, B.M., Armstrong, R.A., 2004. The Kaapvaal Craton and adjacent orogens, southern Africa: a geochronological database and overview of the geological development of the craton. S. Afr. J. Geol. 107, 13-32.

Ferré, E.C., Caby, R., Peucat, J.J., Capdevila, R., Monié, P., 1998. Pan-African, postcollisional, ferro-potassic granite and quartz-monzonite plutons of Eastern Nigeria. Lithos 45, 255-279.

Frost, B.R., Barnes, C.G., Collins, W.J., Arculus, R.J., Ellis, D.J., Frost, C.D., 2001. A geochemical classification for granitic rocks. J. Petrol. 42, 2033-2048.

Frost, B.R., Frost, C.D., 2008. On charnockites. Gondwana Res. 13, 30-44.

Henderson, D.R., Long, L.E., Barton Jr., J.M., 2000. Isotopic ages and chemical and isotopic composition of the Archaean Turfloop Batholith, Pietersburg granitegreenstone terrane, Kaapvaal Craton, South Africa. S. Afr. J. Geol. 103 (1), 38-46.

Koizumi, T., Tsunogae, T., van Reenen, D.D., 2014. Fluid evolution of partially retrogressed metapelites from the Southern Marginal Zone of the Neoarchean Limpopo Complex, South Africa: evidence from phase equilibrium modelling. Precambrian Res., http://dx.doi.org/10.1016/j.precamres.2014.04.017.

Kreissig, K., Holzer, L., Frei, R., Villa, I.M., Kramers, J.D., Smit, C.A., van Reenen, D.D. 2001. Geochronology of the Hout River Shear Zone and the metamorphism in the Southern Marginal Zone of the Limpopo belt, Southern Africa. Precambrian Res. 109, 145-173.

Kreissig, K., Nagler, T.F., Kramers, J.D., Van Reenen, D.D., Smit, C.A., 2000. An isotopic and geochemical study of the Kaapvaal Craton and the Southern Marginal Zone of the Limpopo belt: are they juxtaposed terranes? Lithos 50, 1-25.

Kröner, A., Jaeckel, P., Brandl, G., 2000. Single zircon ages for felsic to intermediate rocks from the Pietersburg and Giyani greenstone belts and bordering granitoid orthogneisses, northern Kaapvaal Craton, South Africa. J. Afr. Earth Sci. 30 (4), 773-793.

Laurent, O., Paquette, J.-L., Martin, H., Doucelance, R., Moyen, J.-F., 2013. LA-ICP-MS dating of zircons from Meso- and Neoarchean granitoids of the Pietersburg block (South Africa): crustal evolution at the northern margin of the Kaapvaal craton. Precambrian Res. 230, 209-226.

Laurent, O., Rapopo, M., Stevens, G., Moyen, J.-F., Martin, H., Doucelance, R., Bosq, C., 2014. Contrasting petrogenesis of $\mathrm{Mg}-\mathrm{K}$ and $\mathrm{Fe}-\mathrm{K}$ granitoids and implications for post-collisional magmatism: case study from the late-Archean Matok pluton (Pietersburg block, South Africa). Lithos 196, 131-149.

Montel, J.M., Vielzeuf, D., 1997. Partial melting of metagreywackes. 2. Compositions of minerals and melts. Contrib. Mineral. Petrol. 128, 176-196.

Moyen, J.-F., 2011. The composite Archaean grey gneisses: petrological significance, and evidence for a non-unique tectonic setting for Archaean crustal growth. Lithos 123, 21-36.
Moyen, J.-F., Martin, H., 2012. Forty years of TTG research. Lithos 148, 312-336.

Nicoli, G., Stevens, S., Buick, I.S., Moyen, J.-F., 2014. A comment on "Ultrahightemperature metamorphism from an usual corundum+orthopyroxene intergrowth bearing Al-Mg granulite from the Southern Marginal Zone, Limpopo Complex, South Africa” by Belyanin et al. Contrib. Mineral. Petrol. 167, 1022, http://dx.doi.org/10.1007/s00410-014-1022-6.

Patiño Douce, A.E., Harris, N., 1998. Experimental constraints on Himalayan anatexis. J. Petrol. 39, 689-710.

Patiño Douce, A.E., Johnston, A.D., 1991. Phase equilibria and melt productivity in the pelitic system: implications for the origin of peraluminous granitoids and aluminous granites. Contrib. Mineral. Petrol. 107, 202-218.

Pickering, J.M., Johnston, A.D., 1998. Fluid-absent melting behavior of two-mica metapelite: experimental constraints on the origin of Black Hills granite. J. Petrol. 39, 1797-1894.

Peucat, J.J., Capdevila, R., Drareni, A., Mahdjoub, Y., Kahouri, M., 2005. The Eglab massif in the West African Craton (Algeria), an original segment of the Eburnean orogenic belt: petrology, geochemistry and geochronology. Precambrian Res. 136, 309-352.

Rajesh, H.M., 2012. A geochemical perspective on the episodic charnockite magmatism in peninsular India. Geosci. Front. 3, 773-788.

Rajesh, H.M., Santosh, M., Wan, Y., Liu, D., Liu, S.J., Belyanin, G.A., 2014. Ultrahigh temperature granulites and magnesian charnockites: evidence for Neoarchean accretion along the northern margin of the Kaapvaal Craton. Precambrian Res. 246, 150-159.

Rapopo, M., (MSc. thesis) 2010. Petrogenesis of the Matok pluton, South Africa: implications on the heat source that induced regional metamorphism in the Southern Marginal Zone of the Limpopo belt. University of Stellenbosch, South Africa.

Rigby, M., Mouri, H., Brandl, G., 2008. A review of the pressure-temperature-time evolution of the Limpopo belt: constraints for a tectonic model. J. Afr. Earth Sci. $50(2-4), 120-132$.

Roering C., van Reenen, D.D., Smit, C.A., Barton, J.M., de Beer, J.H., de Wit, M.J., Stettler, E.H., van Schalkwyk, J.F., Stevens, G., Pretorius, S., 1992. Tectonic model for the evolution of the Limpopo belt. Precambrian Res. 55, 539-552.

Rollinson, H., 2009. New models for the genesis of plagiogranites in the Oman ophiolite. Lithos 112 (3-4), 603-614

Stevens, G., Clemens, J.D., Droop, G.T.R., 1997. Melt production during granulitefacies anatexis: experimental data from primitive metasedimentary protoliths. Contrib. Mineral. Petrol. 128, 352-370.

Stevens, G., van Reenen, D.D., 1992a. Partial melting and the origin of metapelitic granulites in the Southern Marginal zone of the Limpopo belt, South Africa. Precambrian Res. 55, 303-319.

Stevens, G., van Reenen, D.D., 1992b. Constraints on the form of the P-T loop in the Southern Marginal zone of the Limpopo belt, South Africa. Precambrian Res. 55, 279-296.

Taylor, J., Nicoli, G., Stevens, G., Frei, D., Moyen, J.-F., 2014. The processes that control leucosome compositions in metasedimentary granulites: perspectives from the Southern Marginal Zone migmatites, Limpopo belt, South Africa. J. Metamorph. Geol., http://dx.doi.org/10.1111/jmg.12087.

Vander Auwera, J., Bogaerts, M., Bolle, O., Longhi, J., 2007. Genesis of intermediate igneous rocks at the end of the Sveconorwegian (Grenvillian) orogeny (S Norway) and their contribution to intracrustal differentiation. Contrib. Mineral. Petrol. 156, 721-743.

Vander Auwera, J., Bolle, O., Bingen, B., Liégeois, J.-P., Bogaerts, M., Duchesne, J.-C., de Waele, B., Longhi, J., 2011. Sveconorwegian massif-type anorthosites and related granitoids result frrom post-collisional melting of a continental arc root. Earth Sci. Rev. 107, 375-397.

Vielzeuf, D., Holloway, J.R., 1988. Experimental determination of the fluid-absent melting reactions in the pelitic system. Contrib. Mineral. Petrol. 98, 257-276.

Willbold, M., Hegner, E., Stracke, A., Rocholl, A., 2009. Continental geochemical signatures in dacites from Island and implications for models of early Archaean crust formation. Earth Planet. Sci. Lett. 279 (1-2), 44-52.

Zeh, A., Gerdes, A., 2012. U-Pb and Hf isotope record of detrital zircons from gold-bearing sediments of the Pietersburg Greenstone belt (South Africa) - is there a common provenance with the Witwatersrand Basin? Precambrian Res. 204-205, 46-56.

Zeh, A., Gerdes, A., Barton Jr., J.M., 2009. Archean accretion and crustal evolution of the Kalahari Craton - the Zircon Age and Hf Isotope Record of Granitic Rocks from Barberton/Swaziland to the Francistown Arc. J. Petrol. 50 933-966.

Zeh, A., Jaguin, J., Poujol, M., Boulvais, P., Block, S., Paquette, J.-L., 2013. Juvenile crust formation in the northeastern Kaapvaal Craton at $2.97 \mathrm{Ga}-$ implications for Archean terrane accretion, and the source of the Pietersburg gold. Precambrian Res. 233, 20-43. 